\title{
An unusual case of rectal perforation resulting in extensive surgical emphysema
}

\author{
Yi Jie Lee, Naren N Basu, Umesh Parampalli, David Birch
}

Department of Colorectal Surgery, University Hospital Lewisham, London, UK

Correspondence to Yi Jie Lee, yjlee@doctors.org.uk

\section{DESCRIPTION}

A 62-year-old female presented with a 3-week history of non-specific abdominal pain. She had a history of rectal prolapse and was awaiting rectopexy. Clinical examination revealed gross anterior abdominal wall surgical emphysema (figures 1 and 2) as well as surgical emphysema of the pararectal region on digital rectal examination. There were no signs of peritonitis. A rigid sigmoidoscopy on admission revealed no obvious mucosal abnormality. There was no history of any rectal trauma. An erect chest radiograph confirmed a pneumoperitoneum. A CT scan, performed to identify the site of perforation, revealed a thickened rectosigmoid surrounded by large amounts of free air (figure 3) with extensive surgical emphysema extending to the chest wall and groin. There were large amounts of free air within the retroperitoneal space and around the aorta (figure 4). A diverting sigmoid loopcolostomy was fashioned to allow healing of the rectosigmoid perforation. The patient's postoperative period was unremarkable and she was discharged 1 week later. Spontaneous rectal perforation is an extremely rare condition with only 65 reported cases. ${ }^{1} 2$ The majority of reported cases are either iatrogenic or associated with rectal prolapse. ${ }^{3} 4$ Other causes of rectal perforation include malignancy, diverticular disease, stercoral ulceration, trauma and ulcerative colitis. Constipation and rectal prolapse may lead to stercoral ulceration due to pressure necrosis from fecolomas causing perforation. ${ }^{5}$ A retroperitoneal perforation can make diagnosis difficult due to the lack of symptoms. ${ }^{6}$ Clinical examination and imaging with CT can help with diagnosis and subsequent management.

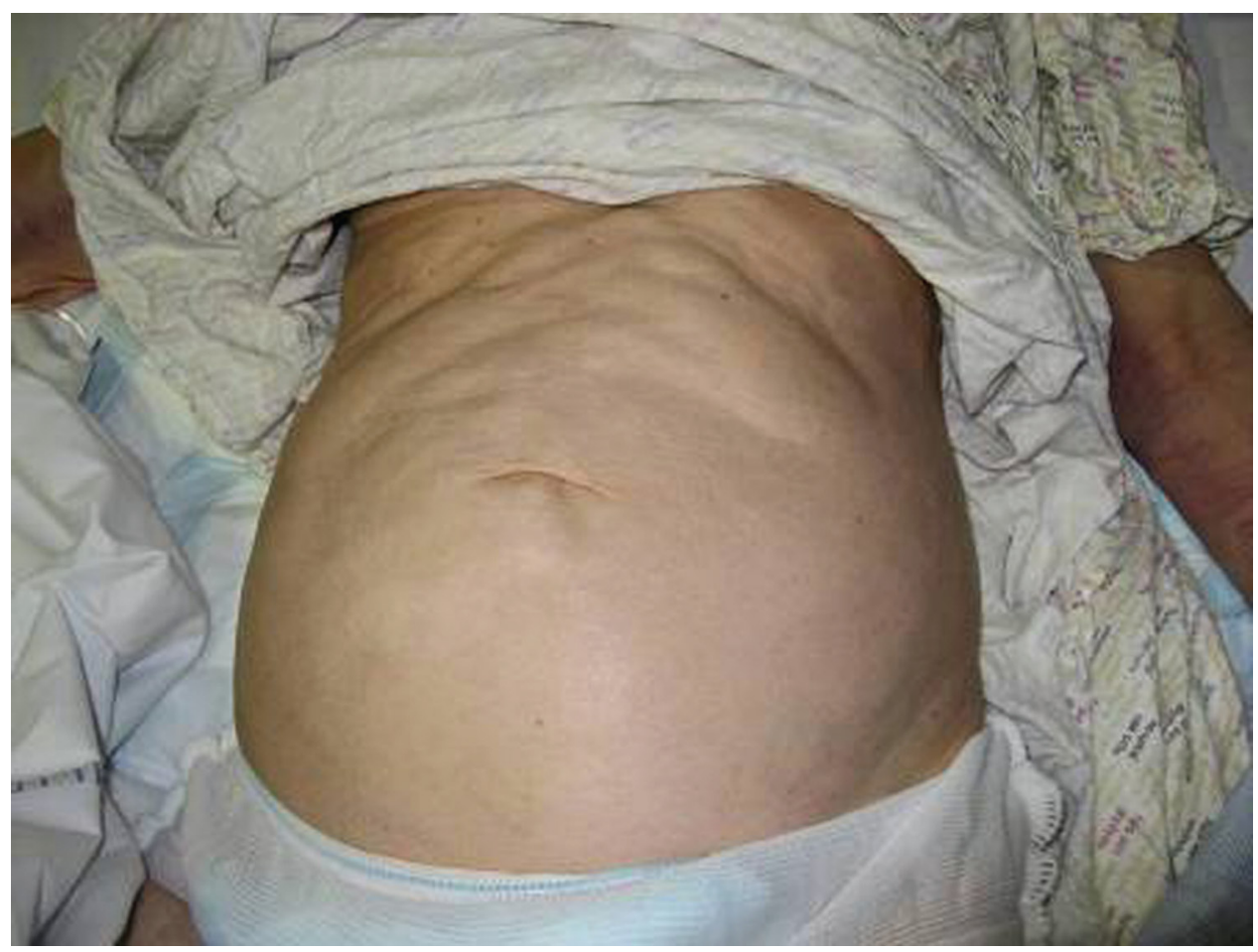

Figure 1 Anterior wall surgical emphysema. 


\section{BMJ Case Reports}

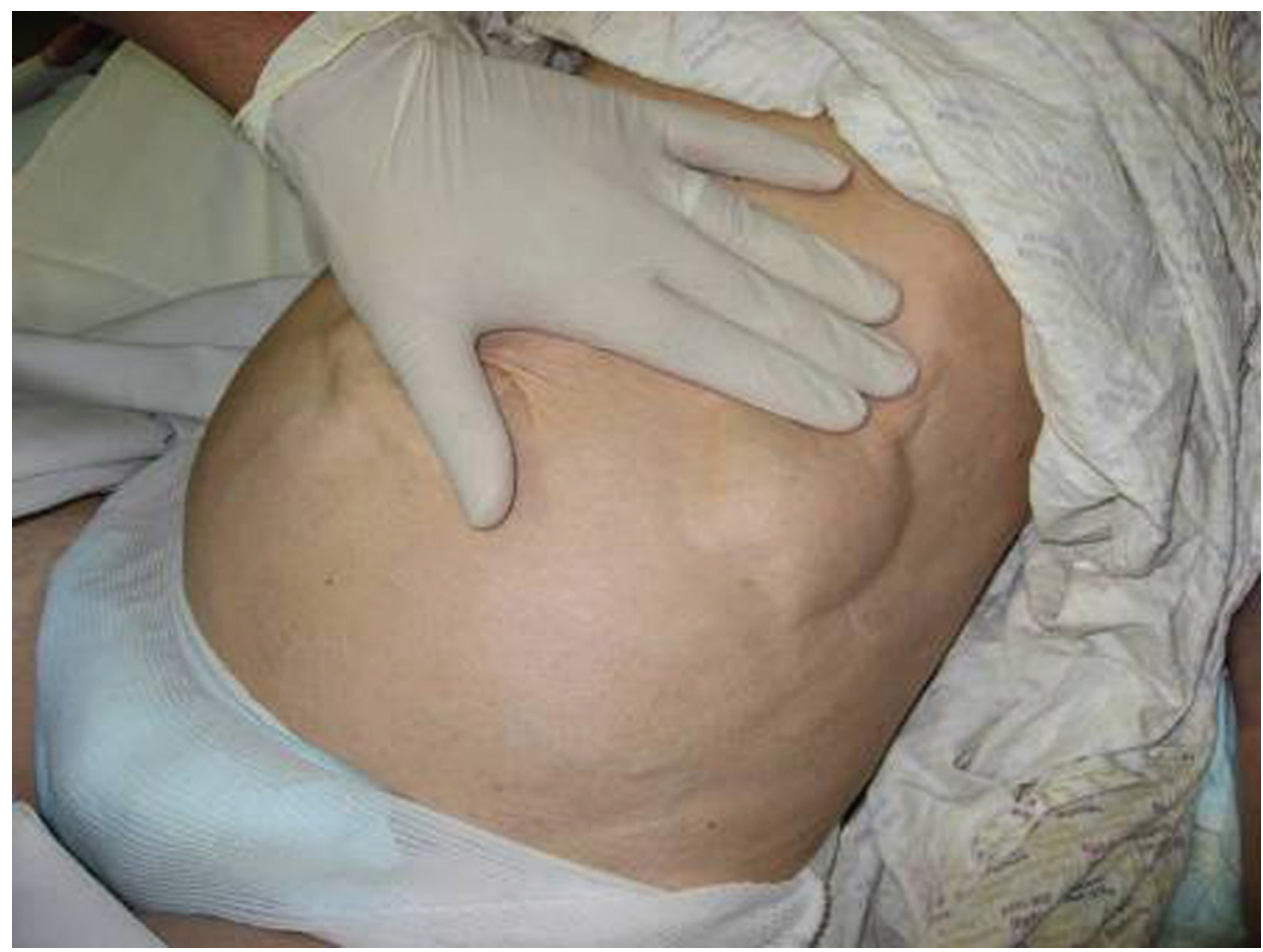

Figure 2 Surgical emphysema prominent on palpation.

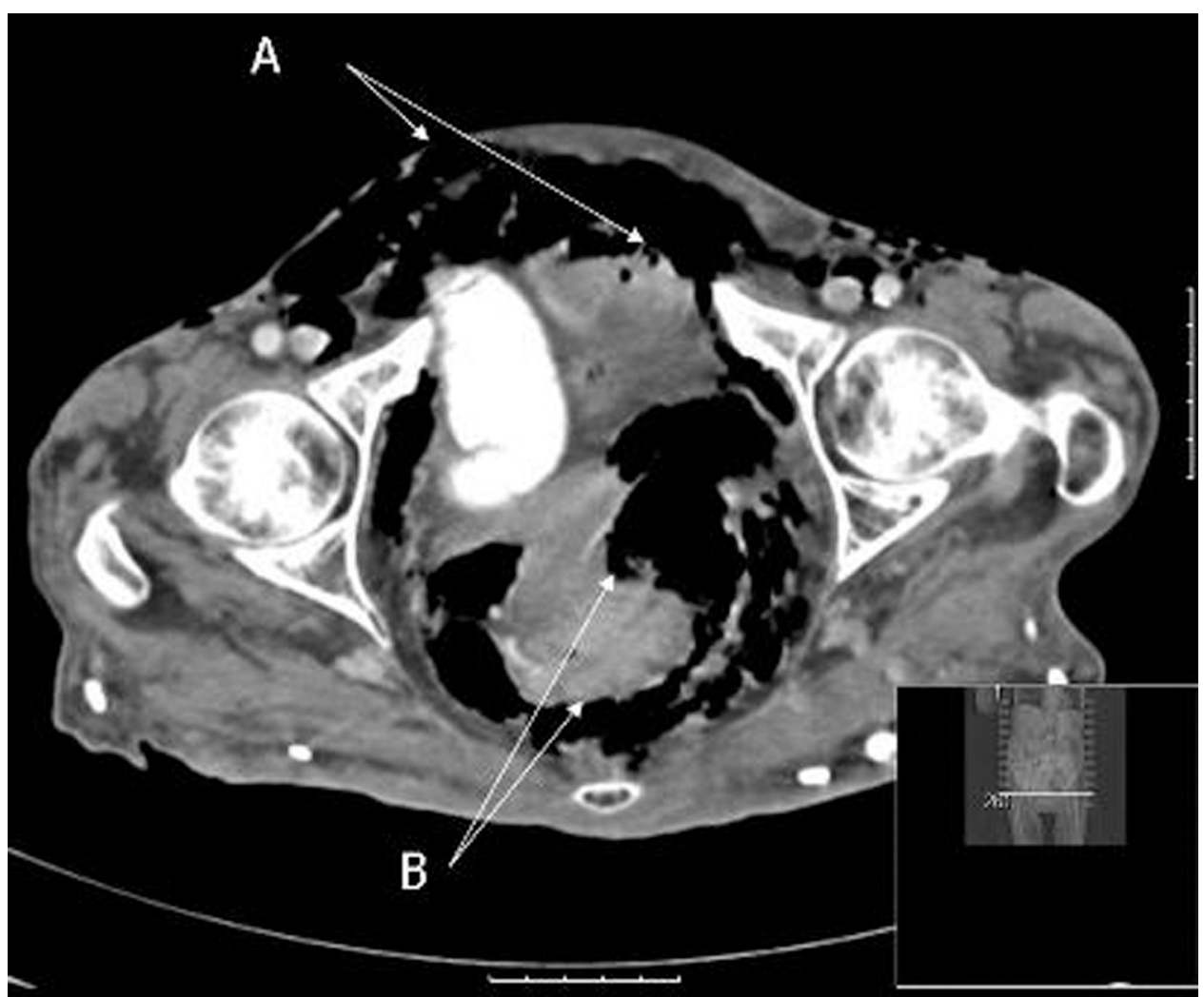

Figure 3 (a) Extensive surgical emphysema in abdominal wall. (b) Thicken rectosigmoid with surrounding air in the pararectal region. 


\section{BMJ Case Reports}

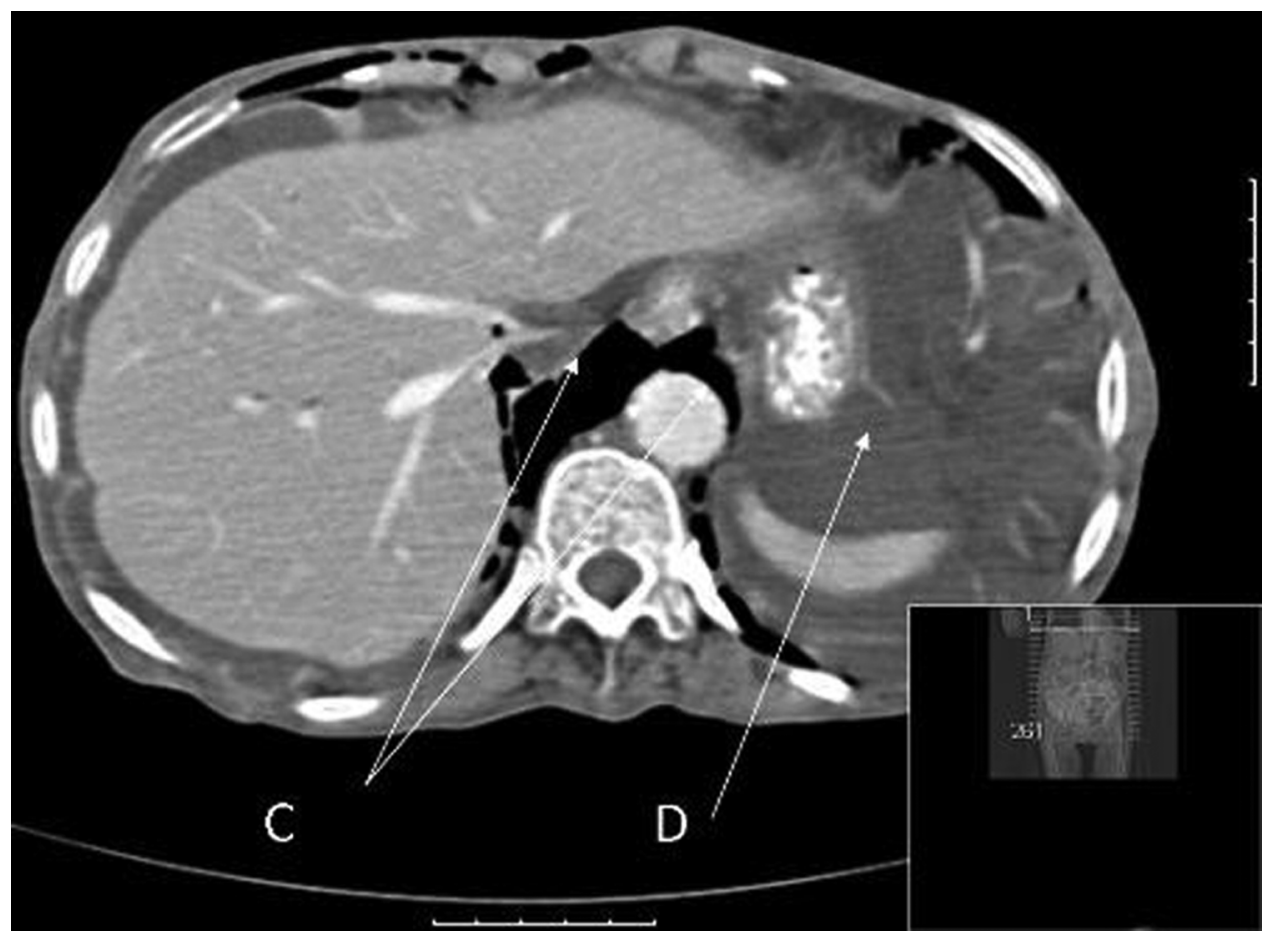

Figure 4 (c) Retroperitoneal free air extending into thorax and around the aorta. (d) Free intra-abdominal fluid.

\section{Competing interests None.}

Patient consent Obtained.

\section{REFERENCES}

1. Ghosal SR, Bhattacharjee PK, Dey KK. Spontaneous rupture of rectum with prolapse of small gut through the anus - a case report. Indian J Surg 2004;66:291-293.

2. Al-Abkari HA. Spontaneous rupture of the rectum with evisceration of omentum through the anus: a case report and review of the literature. Ann Saudi Med 2000:20:246-7.
3. Sekine $\mathbf{Y}$, Ichinose R, Fukumori T, et al. A report of spontaneous rectal rupture successfully treated by emergent operation. Jpn J Gastroenterol Surg 2001;34:1780-1784.

4. Eu KW, Seow-Choen F, Goh HS. Unusual rectal perforation-an individualised approach to management. Singapore Med J 1994;35:79-81.

5. Huang WS, Wang CS, Hsieh CC, et al. Management of patients with stercoral perforation of the sigmoid colon: report of five cases. World $J$ Gastroenterol 2006;12:500-3.

6. Hur T, Chen Y, Shu GH, et al. Spontaneous cervical subcutaneous and mediastinal emphysema secondary to occult sigmoid diverticulitis. Eur Respir J 1995;8:2188-90.

This pdf has been created automatically from the final edited text and images.

Copyright 2012 BMJ Publishing Group. All rights reserved. For permission to reuse any of this content visit http://group.bmj.com/group/rights-licensing/permissions.

BMJ Case Report Fellows may re-use this article for personal use and teaching without any further permission.

Please cite this article as follows (you will need to access the article online to obtain the date of publication).

Lee YJ, Basu NN, Parampalli U, Birch D. An unusual case of rectal perforation resulting in extensive surgical emphysema. BMJ Case Reports 2012;10.1136/bcr.09.2011.4822, Published XXX

Become a Fellow of BMJ Case Reports today and you can:

- Submit as many cases as you like

- Enjoy fast sympathetic peer review and rapid publication of accepted articles

- Access all the published articles

- Re-use any of the published material for personal use and teaching without further permission

For information on Institutional Fellowships contact consortiasales@bmjgroup.com

Visit casereports.bmj.com for more articles like this and to become a Fellow

Keep up to date with all published cases by signing up for an alert (all we need is your email address) http://casereports.bmj.com/cgi/alerts/etoc 